Piwoński Michal, Żak Klaudia, Kozłowska Marta, Zaremba Bartłomiej, Milanowska Joanna. Effects of growth hormonereplacement therapy in patients with Prader-Willi syndrome - review of recent clinical trials. Journal of Education, Health and Sport. 2020;10(8):157-168. eISSN 2391-8306. DOI http://dx.doi.org/10.12775/JEHS.2020.10.08.018

https://apcz.umk.pl/czasopisma/index.php/JEHS/article/view/JEHS.2020.10.08.018

\title{
Effects of growth hormone-replacement therapy in patients with Prader-Willi syndrome - review of recent clinical trials
}

\author{
Michał Piwoński, Klaudia Żak, Marta Kozłowska, Bartlomiej Zaremba, \\ Joanna Milanowska
}

Medical University of Lublin, Poland

Michał Piwoński, e-mail: michalpiwonski2@gmail.com, ORCID:

https://orcid.org/0000-0001-6510-8993

Klaudia Żak, e-mail: zakklaudia3@gmail.com,

ORCID: https://orcid.org/0000-0003-2421-2553

Marta Kozłowska, e-mail: m.kozlowska.med@gmail.com

ORCID: https://orcid.org/0000-0001-7791-508X

Bartlomiej Zaremba, e-mail: zaremba.bartek28@gmail.com, ORCID: https://orcid.org/0000-0002-3255-2745

Joanna Milanowska, e-mail: joannamilanowska@umlub.pl, ORCID: $\underline{\text { https://orcid.org/0000-0001-9741-1583 }}$ 


\begin{abstract}
Introduction and objective: Prader-Willi syndrome (PWS) is a severe genetic disorder being manifested by several symptoms such as infantile hypotonia and poor thriving outcomes, low height, hyperphagia, endocrine, reproductive and internal malfunctions and malformations. In the disease treatment, growth hormone (GH)-replacement therapy is commonly carried on. In this article, we sum up the latest clinical trials' results concerning the effectiveness and safety of GH-replacement therapy.
\end{abstract}

Abbreviated description of the state of knowledge: Taking into consideration six clinical trials performed in the years 2019-2020, most of them showed positive results of GHreplacement therapy in PWS patients, not only in case of better motor skills or body composition, but also concerning their social and adaptive functioning. Moreover, as for the cessation of GH treatment, some authors seem to highlight no deterioration in cognitive functioning in patients who attained adult height after GH-treatment.

Summary: GH-replacement therapy seems to be a good therapeutic option for PWS-affected individuals. Nonetheless, in our research we did not come across on any clinical trials with more than one-year-long observations. Thus, on the long term, these results can not exclude a gradual deterioration of cognitive functioning.

Key words: Prader-Willi syndrome therapy, Hormone Replacement Therapy, Growth Hormone therapeutic use

\title{
Introduction and objective
}

Prader-Willi syndrome (PWS) is known as a multisystem disorder with prevalence estimated to be between 1:10,000 and 1:20,000 births, more commonly in the Caucasian race (1). First cases were reported by Prader, Labhart, and Willi in 1956. In 1981, according to the results of Ledbetter et al. it was proven that an interstitial deletion in the proximal long arm of chromosome 15 is responsible for the pathogenesis of the disorder (2).

The DNA region involved in the symptoms expression comprises a 5-6 Mb genomic region on the proximal long arm of chromosome 15 (15q11.2-q13). The expression of relevant genes in the 15q11.2-q13 region is dependent on paternal origin, that's why the PWS is an example of an imprinted condition. No maternal contribution for these genes, silenced by epigenetic factors, results in lack of expression in case of absence of paternally inherited copies of involved genes (3).

Clinical manifestations of the disease are mainly the effects of the disruption in the hypothalamic-pituitary axis and growth hormone $(\mathrm{GH})$ deficiency which causes the changes which can be detected in utero, such as low prenatal weight, below-average height and, subsequently, poor growth velocity. These features are stated to be about 15-20 per cent lower than in the cases of siblings with no genetic changes (3). As for the other musculoskeletal changes, in PWS-affected individuals, there is also prenatal hypotonia (persisting throughout infancy), lethargy, poor suck (diminishing the abilities to thrive), scoliosis (being developed before the age of ten years) and hand dysmorphisms $(4,5)$. 
Regarding other clinical manifestations, we can distinguish also: delayed motor development during infancy (with a higher amount of time to achieve motor and language milestones, even though the verbal competence seem to be a strong point (6)), mild disability with a mean IQ of $60-70$. There is also a characteristic behavioral profile which involves compulsivity, obstinacy, temper frenzies and manipulative behavior (7).

Moreover, there is also a large group of clinical manifestations concerning the endocrine and reproductive symptoms. In PWS-affected individuals, thyroid axis dysfunction is often present. Besides, hyperphagia, decreased physical activity, hypersomnolence, hypotonia lead to diabetes mellitus type II development. In PWS, there is also a hypothalamus-pituitaryadrenal axis disruption, leading to central adrenal insufficiency (CAI) which is considered to be very common. As for the lack of $\mathrm{GH}$, short stature is a clinical manifestation present in about $85 \%$ of individuals, manifesting in childhood, but visible the most significantly with no administration of $\mathrm{GH}$ by the second decade of life. On average, it is stated that the standard adult height is about 2 standard deviations lower than in case of general population. Moreover, hyperphagia is one the most common and well-known symptoms. Fat in PWS individuals is stored centrally in the abdomen, buttocks, and thighs with no difference as for the gender and with lower visceral fat than expected $(4,5,8)$. Concerning the reproductive system malfunctions, in PWS there is hypogonadism resulting in delayed and incomplete puberty but also in infertility in most PWS patients. On the other hand, there is also early adrenarche and precocious puberty (8).

Prader-Willi syndrome is a disease that leads to multiple complications, which is why its treatment consists mainly of alleviating them. PWS treatment includes both pharmacological and behavioral treatment. Until the 1990s, treatment was focused on a low-calorie diet and physiotherapy, but despite the close control of doctors and caregivers in most people, this was not enough to prevent morbid obesity. Over the past 20 years, extensive work has been done to find a way to treat adults and children, which has resulted in significant progress. $[9,10]$ According to the current guidelines of the Polish Society of Endocrinology in 2018, the main goal of treatment of Prader-Willi Syndrome is to prevent the development of obesity and associated diseases, as well as early diagnosis and treatment of metabolic complications, therapy of hormonal disorders, stabilization of mental health and physiotherapy to treat of scoliosis, which is a common complication of obesity [10]. In order to reduce the risk of obesity, regular physical activity [11] and adherence to a balanced diet, which should constitute about $60-70 \%$ of the recommended daily intake, are very important [12]. It has been shown that a diet containing 30\% fat, $45 \%$ carbohydrates, $25 \%$ protein and at least $20 \mathrm{~g}$ fiber has a beneficial effect on maintaining a constant body weight of people with PWS [11]. Growth hormone secretion disorder present in Prader-Willi Syndrome [13] is treated with growth hormone replacement therapy, which is used to increase growth and improve body composition by compensating for metabolic disorders. It has also been shown to have a positive effect on cognitive development in children $[14,15]$. In order to prevent mental disorders and morbid obesity as a consequence of growth hormone deficiency, its administration should be continued in adult patients [16].

Diet and exercise alone are not enough, especially for people who are diagnosed in adulthood. Pharmaceutical companies are looking for drugs that would prevent hyperphagia (voracious eating) by suppressing appetite, make you feel full faster, and improve carbohydrate 
metabolism. Currently, clinical trials on drugs, such as setmelanotide, GLP-1 agonists, AZP531, oxytocin and diazoxide are underway, the results of which are promising and possible to be implemented in the coming years for the treatment of people with Prader-Willi Syndrome [17].

GH deficiency is not the only endocrine disorder. Substitution in the field of sex hormones, whose deficiency is responsible for hypogonadism, is also important. For its treatment, hormone replacement therapy (HRT) that is started during puberty is recommended and should be continued in adults. The use of HRT in patients with PWS contributes to an increase in bone mineral density (protection against osteoporosis), metabolic protection of muscle tissue, restoration of menstruation in women, and also has a beneficial effect on mental health [16].

Carbohydrate metabolism disorders together with obesity in these people contribute to the development of insulin resistance, followed by type 2 diabetes [18]. In this case, it is recommended to use metformin, which increases tissue sensitivity to insulin. Treatment with this drug is well tolerated and effective [11].

Thyroid hormone levels should also be monitored in these patients due to hypothyroidism in some patients [19]. If hypothyroidism occurs, treatment with L-thyroxine should be started.

The aim of this work is to sum up the most recent clinical trials, from the years 20152019, available in the PubMed base, concerning the results of GH-replacement therapy with usage of keywords: Prader-Willi syndrome therapy, Hormone Replacement Therapy, Growth Hormone therapeutic use. In this analysis, we took into account six clinical trials.

\section{Description of the state of knowledge}

From the therapeutic view, obesity and hormonal deficiencies (especially of growth hormone) seem to be the most important signs. According to the existing recommendations concerning the GH-replacement therapy, growth hormone is used successfully for treating infants as early as 2 months of age once the diagnosis of PWS is genetically confirmed [20]. Below, we represent the newest clinical trials showing the results of GH-replacement therapy.

\section{N. E Bakker, R. J. Kuppens et al. (2015) [21]}

N. E. Bakker wanted to check how the long-term GH treatment influences bone mineral density (BMD) in children and adolescents with genetically confirmed diagnosis of PraderWilli syndrome. The first part of the study included 77 children who remained prepubertal during 4 years of the study and to the second part of the study 64 children who continued GH treatment for 8 to 11 years were qualified. 11 patients ( 6 girls and 5 boys) during the study received sex hormone replacement treatment. In children with PWS, BMD of total body $\left(\mathrm{BMD}_{\mathrm{TB}}\right)$, lumbar spine $\left(\mathrm{BMD}_{\mathrm{LS}}\right)$ and bone mineral apparent density of lumbar spine $\left(B_{M A D}\right)$ were measured. The results were expressed in standard deviation scores (SDS). Biosynthetic GH was administered once a day at bedtime - the first four weeks in the dose of $0,5 \mathrm{mg} / \mathrm{m} 2 /$ day and after that of $1 \mathrm{mg} / \mathrm{m} 2 /$ day.

In prepubertal children during 4 years of GH bone mineral the density changed.

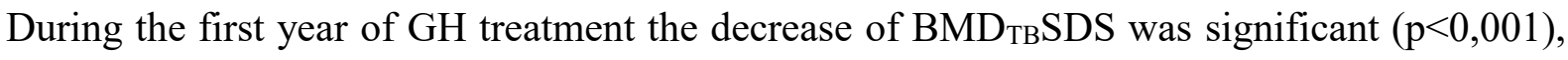
while after 4 years of $\mathrm{GH}$ treatment, $\mathrm{BMD}_{\mathrm{TB}} \mathrm{SDS}$ increased $(\mathrm{p}=0,001)$. In addition, an 
increase of $\mathrm{BMD}_{\mathrm{TB}} \mathrm{SDS}$ and $\mathrm{BMD}_{\mathrm{LS}} \mathrm{SDS}$ was mentioned. BMAD $\mathrm{LSSDS}_{\mathrm{LS}}$ was between 0 and 1 SDS.

After 9 years of treatment 64 children the $\mathrm{BMD}_{\mathrm{TB}} \mathrm{SDS}$ was not significantly different in comparison with the beginning of study $(\mathrm{p}=0,716)$, but it was significantly different between BMD $_{\mathrm{TB}}$ SDS after 4 and 9 years of treatment $(\mathrm{p}=0,001)$. The same was about BMDLSSDS - it was lower after 9 years when compared to the results obtained after 4 years of GH treatment. The BMADLSSDS decreased during the last 5 years of treatment.

\section{N. E Bakker, E. P. C. Siemensma et al. (2015) [22]}

N. E. Bakker checked also in a Randomized Controlled Trial (RCT) and Longitudinal Study an impact of Growth Hormone Treatment on Health-Related Quality of Life. 24 children took part in the RCT while 76 - in the long-term study. GH in the dose $1,0 \mathrm{mg} / \mathrm{m} 2 /$ day was administered once per day at bedtime. In order to the HRQOL measurement, two questionnaires: the Dutch Children AZL/TNO Questionnaire Quality of Life short form (DUX25) and a PWS-specific questionnaire, the DUX Prader Willi (DUXPW) were used. The first one assesses 4 subdomains: Physical, Home, Emotional and Social functioning in scores from 0 to 100 .

2 years-long GH-treated children with PWS in comparison with untreated children with PWS had significantly higher score in the physical subdomain $(p<0,05)$, the total DUX25 score in GH-treated children was not significantly higher $(\mathrm{p}=0.07)$. Parents of $\mathrm{GH}-$ treated children in comparison with the parents of untreated children reported higher score in Physical $(p<0,01)$ and Emotional $(p<0,05)$ subdomains.

In the long-term study group the positive effect disappeared, which could not be due to the $\mathrm{GH}$ treatment. After 11 years of $\mathrm{GH}$ treatment the Physical subdomain was not significantly different when compared to the beginning ( $p=0,001)$, even though, after 2 years, the difference was relevant. The same was about Home subdomain - after 4 years a significant increase was observed $(p=0,002)$, but after 11 years it was not different in comparison with the baseline. Parents of older children had significantly lower HRQOL than parents of younger ones $(p=0,009)$.

\section{S. T. Lo, D. A. M. Festen et al. (2015) [23]}

The next study included 42 infants and 33 prepubertal children with genetically confirmed diagnosis of PWS in order to assess the effects of long-term GH treatment on adaptive functioning in children with PWS. GH in the dose of $1,0 \mathrm{mg} / \mathrm{m} 2 /$ day in the bedtime or placebo were administered. In this research adaptive functioning (in 4 domains: communication, daily living skills, socialization and motor skills) was measured by the Dutch version of the Vineland Adaptive Behavior Scale (VABS) with cognitive functioning assessment was performed by a psychologist, blinded for the randomization. After 7 years of continuous GH treatment the first follow-up was made and 22 patients were excluded, so finally 53 children took part in randomized controlled trial.

1 or 2 years of treatment did not have an impact on adaptive functioning including communication $(p=0,262)$, daily living skills $(p=0,295)$, socialization $(p=0,605)$ and motor skills $(p=0,727)$. After 7 years of treatment in the untreated group the delay was significantly lower in all domains: communication $(\mathrm{p}<0,001)$, daily living skills $(\mathrm{p}<0,001)$, socialization 
$(p<0,001)$ and motor skills $(p<0,001)$. In addition, the earlier growth hormone treatment was started, the better adaptive skills were on the long-term - in communication $(p=0,018)$, daily living skills $(p=0,041)$, socialization $(p=0,048)$ and motor skills $(p=0,003)$.

\section{R. J. Kuppens, N. E. Bakker, et. al. (2016) [24]}

In 2016, the results of two-year, randomized, double-blind, placebo-controlled, crossover study results concerning GH treatment in young adults with PWS were published. It involved 33 patients with adult height attainment (which was defined as a height velocity less than 0.5 cm per 6 months), who completed epiphyseal fusion. They were also treated with GH during their childhood for at least 2 years and being on GH at time of inclusion. Moreover, no one from this group used any drugs associated with weight loss and did not show behaviour connected with no desire to cooperate.

During the study, Renske J. Kuppens et. al. were investigating the effects of 1-year placebo vs 1-year GH therapy on body composition, which were measured by checking, among others, fat mass percentage $(\mathrm{FM} \%)$ and lean body mass (LBM) with dual-energy $\mathrm{x}$-ray absorptiometry usage.

All patients were randomly and blindy assigned to receive $0.67 \mathrm{mg} / \mathrm{m} 2 / \mathrm{d} \mathrm{GH}$ dose or 1-year with placebo, after that they crossed over for one next year. FM decrease (2.9 kg; P. 004) and an increase in LBM (1.5 kg; P. 005) after GH treatment were observed.

On the other hand, during placebo, FM increased (relative change 21.5\%; P .001). It was also observed that there was no difference in results between boys and girls nor in the group which was treated also with sex steroid replacement therapy and between this one, which was not.

\section{A. M. Hyde, F. A. Chavoya, et. al. (2018) [25]}

Hyde M. A. et. al. conducted the study, aim of which was to establish metabolic variations while walking in PWS patients, non-syndromic obesity children (NSO) and children with normal weight $(\mathrm{NW})$. NW $(\mathrm{n}=9)$ were defined children having a BMI lower than the 85th percentile and NSO $(\mathrm{n}=9)$ were defined as at least having a BMI at 95 percentile. Every group was the same for age and sex. It involved 27 patients, nine of them had documented PWS, and eight of them had had GH therapy at least for two years during the study and received daily doses of $\mathrm{GH}$ ranged from $0,3 \mathrm{mg}$ to $2,0 \mathrm{mg}$.

Participants walked three 5 min.-long parts on a treadmill and after every bount they had 6 min-seated rest period. Children walks were at speeds of $3.2,4,4.8 \mathrm{k} / \mathrm{h}$, the order of walking speeds was randomized. Measurements during the study included, among others: walking energy expenditure (WEE), heart rate, body composition and utilization of fat and carbohydrate.

As it was observed, children with PWS had higher heart rate and the same walking energy expenditure (WEE) in comparison to controls.

What is more, at every speed PWS patients spent more WEE than children with nonsyndromic obesity, but similar in comparison to children with normal weight.The results may help in tailor the type and intensity of physical exercises for children with PWS to manage optimal weight for them. 
R. Corripio, C. Tubau, et. al. (2019) [26]

In 2019 results of the study were published, aim of which was to check the safety and the effects of GH therapy in patients younger than 2 years with confirmed PWS by DNA methylation test. Corripio R. et. al. wanted to evaluate changes in body weight, height and the age, when patients start to walk and talk. They used Body mass index (BMI) SDS, height standard deviation score (SDS) and measured subscapular and tricipital skinfolds. All parameters were evaluated at every control visit, once in 3 months and calculated it due to Spanish normative charts.

Their single-center, prospective and also non-controlled study involved 14 patients. They received in the beginning of the treatment the recombinant human $\mathrm{GH}$ at doses of 0,025 $\mathrm{mg} / \mathrm{kg} /$ day, and later they were treated with higher doses $(0,035 \mathrm{mg} / \mathrm{kg} /$ day $)$. As it was observed earlier beginning of GH treatment (before the age of 2 years) resulted in lower BMI and increase in patients' height. Furthermore those who received GH before 15 months of age, started to walk about 18 months of age, hence before the other PWS-affected children. What is more, none of the patients developed diabetes mellitus, hypercholesterolemia, hypothyroidism nor scoliosis, which are characteristic for PWS.

Tab. 1 Clinical trials showing the results of GH-replacement therapy

\begin{tabular}{|l|l|l|l|l|l|l|l|}
\hline Title & Date & Authors & $\begin{array}{l}\text { Measure- } \\
\text { ments }\end{array}$ & Study group & GH dose & $\begin{array}{l}\text { Method } \\
\text { of GH } \\
\text { administ- } \\
\text { ration }\end{array}$ & \begin{tabular}{l} 
Results \\
\hline
\end{tabular} \\
\hline
\end{tabular}




\begin{tabular}{|c|c|c|c|c|c|c|c|}
\hline $\begin{array}{l}\text { Bone Mineral Density in } \\
\text { Children and Adolescents } \\
\text { with Prader-Willi } \\
\text { syndrome: A longitudinal } \\
\text { study during puberty and } \\
9 \text { years of Growth } \\
\text { Hormone treatment }\end{array}$ & 2015 & $\begin{array}{l}\text { N. E } \\
\text { Bakker, R. } \\
\text { J. Kuppens } \\
\text { et al. }\end{array}$ & $\begin{array}{l}\text { Bone mineral } \\
\text { density of total } \\
\text { body }\left(\mathrm{BMD}_{\mathrm{tb}}\right) \text {, } \\
\text { lumbar spine } \\
\left(\mathrm{BMD}_{\mathrm{ls}}\right) \text { and bone } \\
\text { mineral apparent } \\
\text { density of the } \\
\text { lumbar spine } \\
\left(\mathrm{BMAD}_{\mathrm{ls}}\right)\end{array}$ & $\begin{array}{l}77 \text { who } \\
\text { remained } \\
\text { prepubertal } \\
\text { during } \mathrm{GH} \\
\text { treatment for } 4 \\
\text { years and } 64 \\
\text { children who } \\
\text { received GH } \\
\text { treatment for } 9 \\
\text { years }\end{array}$ & $\begin{array}{l}1 \mathrm{mg} / \mathrm{m}^{2} / \\
\text { day }(0.035 \\
\mathrm{mg} / \mathrm{kg} / \\
\text { day })\end{array}$ & $\begin{array}{l}\text { subcuta- } \\
\text { neous, at } \\
\text { bedtime }\end{array}$ & $\begin{array}{l}\text { In the prepubertal } \\
\text { group an increase of } \\
\text { BMD }_{\mathrm{TB}} \mathrm{SDS} \text {, } \\
\text { BMD }_{\mathrm{LS}} \mathrm{SDS} \text { and a } \\
\text { stability of } \\
\text { BMAD } \mathrm{DSS}_{\mathrm{LS}} \mathrm{SD} \text { during } \\
\text { GH treatment were } \\
\text { noticed }\end{array}$ \\
\hline $\begin{array}{l}\text { Beneficial Effect of Growth } \\
\text { Hormone Treatment on } \\
\text { Health-Related Quality of } \\
\text { Life in Children with } \\
\text { Prader-Willi Syndrome: A } \\
\text { Randomized Controlled } \\
\text { Trial and Longitudinal } \\
\text { Study. }\end{array}$ & 2015 & $\begin{array}{l}\text { N. E } \\
\text { Bakker, E. } \\
\text { P. C. } \\
\text { Siemensma } \\
\text { et al. }\end{array}$ & $\begin{array}{l}\text { Health-related } \\
\text { quality of life } \\
\text { (HRQOL) }\end{array}$ & $\begin{array}{l}26 \text { children in } \\
\text { randomized } \\
\text { controlled trial } \\
\text { (RCT) and } 76 \\
\text { children in } \\
\text { long-term } \\
\text { group }\end{array}$ & $\begin{array}{l}1 \mathrm{mg} / \mathrm{m}^{2} / \\
\text { day }\end{array}$ & $\begin{array}{l}\text { subcuta- } \\
\text { neous, at } \\
\text { bedtime }\end{array}$ & $\begin{array}{l}\text { GH-treated children } \\
\text { with PWS reported } \\
\text { higher score in } \\
\text { Physical and Social } \\
\text { subdomains. HRQOL } \\
\text { increased during GH } \\
\text { treatment, in contrast } \\
\text { to HRQOL in } \\
\text { untreated group. }\end{array}$ \\
\hline $\begin{array}{l}\text { Beneficial Effects of Long- } \\
\text { Term Growth Hormone } \\
\text { Treatment on Adaptive } \\
\text { Functioning in Infants With } \\
\text { Prader-Willi Syndrome }\end{array}$ & 2015 & $\begin{array}{l}\text { S. T. Lo, D. } \\
\text { A. M. } \\
\text { Festen } \\
\text { et al. }\end{array}$ & $\begin{array}{l}\text { Adaptive } \\
\text { functioning } \\
\text { measured by } \\
\text { Vineland } \\
\text { Adaptive } \\
\text { Behavior Scale } \\
\text { (VABS) (This } \\
\text { scale assesses } 4 \\
\text { domains: } \\
\text { communication, } \\
\text { daily living, skills, } \\
\text { socialization and } \\
\text { motor skills) }\end{array}$ & $\begin{array}{l}75 \text { children (42 } \\
\text { infants and } 33 \\
\text { prepubertal } \\
\text { children) }\end{array}$ & $\begin{array}{l}1 \mathrm{mg} / \mathrm{m}^{2} / \\
\text { day }\end{array}$ & $\begin{array}{l}\text { subcuta- } \\
\text { neous, at } \\
\text { bedtime }\end{array}$ & $\begin{array}{l}\text { Short GH treatment } \\
\text { (1-2 years) does not } \\
\text { have an impact on } \\
\text { adaptive functioning } \\
\text { of the child. The } \\
\text { earlier growth } \\
\text { hormone treatment } \\
\text { was started during } \\
\text { infancy, the better the } \\
\text { adaptive skills were } \\
\text { on the long-term. }\end{array}$ \\
\hline $\begin{array}{l}\text { Metabolic responses to } \\
\text { walking in children with } \\
\text { Prader-Willi syndrome on } \\
\text { growth hormone } \\
\text { replacement therapy }\end{array}$ & 2018 & $\begin{array}{l}\text { A. M. } \\
\text { Hyde, F. A. } \\
\text { Chavoya, } \\
\text { et. al. }\end{array}$ & $\begin{array}{l}\text { metabolic } \\
\text { variations during } \\
\text { walking }\end{array}$ & $\begin{array}{l}26 \text { ( } 8 \text { patients } \\
\text { with PWS on } \\
\text { at least } 2 \text { years } \\
\text { GH therapy } \\
\text { during the }\end{array}$ & $\begin{array}{l}\text { from } 0.3 \\
\mathrm{mg} \\
\text { day to } 2.0 \\
\text { mg day }\end{array}$ & daily & $\begin{array}{l}\text { Children with PWS } \\
\text { had higher heart rate } \\
\text { and the same walking } \\
\text { energy expenditure } \\
\text { (WEE) in comparison }\end{array}$ \\
\hline
\end{tabular}




\begin{tabular}{|c|c|c|c|c|c|c|c|}
\hline & & & & $\begin{array}{l}\text { study, } 9 \text { with } \\
\text { non-syndromic } \\
\text { obesity - BMI } \\
\text { equal or } \\
\text { greater than } 95 \\
\text { percentile, } 9 \\
\text { patients with } \\
\text { normal weight } \\
\text { - lower than } \\
\text { the } 85 \text { th } \\
\text { percentile } \\
\text { for age and } \\
\text { sex) }\end{array}$ & & & $\begin{array}{l}\text { to controls. At every } \\
\text { speed PWS patients } \\
\text { spent more WEE than } \\
\text { children with non- } \\
\text { syndromic obesity. }\end{array}$ \\
\hline $\begin{array}{l}\text { Safety and effectiveness of } \\
\text { growth hormone therapy in } \\
\text { infants with Prader-Willi } \\
\text { syndrome younger than } 2 \\
\text { years: a prospective study }\end{array}$ & 2019 & $\begin{array}{l}\text { R. Corripio, } \\
\text { C. Tubau, } \\
\text { et. al. }\end{array}$ & $\begin{array}{l}\text { Body mass index } \\
\text { (BMI) SDS, height } \\
\text { standard deviation } \\
\text { score (SDS), } \\
\text { the age of } \\
\text { beginning the } \\
\text { speech and the } \\
\text { start of walking }\end{array}$ & $\begin{array}{l}14 \text { (under the } \\
\text { age of } 2 \text { years } \\
\text { with confirmed } \\
\text { PWS by DNA } \\
\text { methylation } \\
\text { test) }\end{array}$ & $\begin{array}{l}0,025 \\
\mathrm{mg} / \mathrm{kg} \\
/ \text { day } \\
\text { during the } \\
\text { first weeks } \\
\text { of treat- } \\
\text { ment, later } \\
0,035 \\
\mathrm{mg} / \mathrm{kg} / \\
\text { day }\end{array}$ & daily & $\begin{array}{l}\text { Earlier beginning of } \\
\text { GH treatment (before } \\
\text { the age of } 2 \text { years) } \\
\text { results in lower BMI, } \\
\text { increase in patients' } \\
\text { height and earlier start } \\
\text { of walking, for these } \\
\text { who received } \\
\text { hormone before } 15 \\
\text { months of age }\end{array}$ \\
\hline
\end{tabular}

\section{Summary}

As for the results of presented clinical trials, most of them show positive results of GH-replacement therapy in PWS patients, not only in case of better motor skills or body composition [21,24,25,26], but also concerning their social and adaptive functioning [22,23]. As for adaptive functioning development, it was stated that only the long-term therapy has its significant effects ( $>2$ years). Moreover, as for the cessation of GH treatment, some authors seem to highlight no deterioration in cognitive functioning in patients who attained adult height after GH-treatment. This kind of retrogressions can be observed among patients with lower IQ levels [27]. Nonetheless, in our research we did not come across on any clinical trials with more than one-year-long observations. Thus, on the long term, these results can not exclude a gradual deterioration of cognitive functioning. What's more, it was also stated that there are no adverse effects on metabolic health profile concerning the GH-replacement therapy, that is why there is no indications for therapy discontinuation after adult height attainment [28].

Hence, GH-replacement therapy seems to be a good therapeutic option for PWSaffected individuals. Still, it is necessary to carry on the clinical trials with longer-term observational period as no such results can be found in the achievable literature.

\section{References}

1. Abdilla Y, Andria Barbara M, Calleja-Agius J. Prader-Willi Syndrome: Background and Management. Neonatal Netw NN. 2017 May 1;36(3):134-41. https://doi.org/10.1891/0730-0832.36.3.134 
2. Ledbetter DH, Riccardi VM, Airhart SD, Strobel RJ, Keenan BS, Crawford JD. Deletions of chromosome 15 as a cause of the Prader-Willi syndrome. N Engl J Med. 1981 Feb 5;304(6):325-9. https://doi.org/10.1056/NEJM198102053040604

3. Cassidy SB, Schwartz S, Miller JL, Driscoll DJ. Prader-Willi syndrome. Genet Med Off J Am Coll Med Genet. 2012 Jan;14(1):1026.https://doi.org/10.1038/gim.0b013e31822bead0

4. Jin D-K. Endocrine problems in children with Prader-Willi syndrome: special review on associated genetic aspects and early growth hormone treatment. Korean J Pediatr. 2012 Jul;55(7):224-31. https://doi.org/10.3345/kjp.2012.55.7.224

5. Girardot M, Cavaillé J, Feil R. Small regulatory RNAs controlled by genomic imprinting and their contribution to human disease. Epigenetics. 2012 Dec 1;7(12):1341-8. https://doi.org/

6. Butler MG. Genomic imprinting disorders in humans: a mini-review. J Assist Reprod Genet. 2009 Oct;26(9-10):477-86. https://doi.org/10.4161/epi.22884

7. Ho AY, Dimitropoulos A. Clinical management of behavioral characteristics of Prader-Willi syndrome. Neuropsychiatr Dis Treat. 2010;6:107-18. https://doi.org/10.2147/ndt.s5560

8. Emerick JE, Vogt KS. Endocrine manifestations and management of Prader-Willi syndrome. Int J Pediatr Endocrinol. 2013 Aug 21;2013(1):14. https://doi.org/10.1186/16879856-2013-14

9. Libura M. Moje dziecko ma zespół Pradera-Williego - jak mogę mu pomóc? Wydawnictwo Polskie Stowarzyszenie Pomocy Osobom z Zespołem Pradera-Williego. Warsaw, 2007, p. 12-22.

10. Góralska M, Bednarczuk T, Rosłon M, Libura M, Szalecki M, Hilczer M, Stawerska R, Smyczyńska J, Karbownik-Lewińska M, Walczak M, Lewiński A. Management of PraderWilli Syndrome (PWS) in adults - what an endocrinologist needs to know. Recommendations of the Polish Society of Endocrinology and the Polish Society of Paediatric Endocrinology and Diabetology. Endokrynologia Polska Tom/Volume 69; Numer/Number 4/2018 ISSN 0423-104X. https://doi.org/10.5603/EP.2018.0047

11. Miller JL, Lynn CH, Shuster J, Driscoll DJ. A reduced energy intake, well-balanced diet improves weight control in children with Prader-Willi syndrome. J Hum Nutr Diet. 2013;26(1):2-9. https://doi.org/10.1111/j.1365-277X.2012.01275.x

12. Alsaif M, Elliot SA, Mackenzie ML, Prado CM, Field CJ, Haqq AM. Energy metabolism profile in individuals with Prader-Willi syndrome and implications for clinical management: a systematic review. Adv Nutr. 2017;8(6):905-915. https://doi.org/10.3945/an.117.016253

13. Petriczko E, Horodnicka-Józwa A, Szmit-Domagalska J, et al. Aspekty endokrynne zespołu Pradera i Williego u dzieci i młodzieży. Pediatria Polska. 2008; 83(5): 522-528, doi: 10.1016/s0031-3939(08)70217-8. https://doi.org/10.1016/S0031-3939(08)70217-8

14. Bakker NE, Lindberg A, Heissler J, et al. KIGS Steering Committee. Growth Hormone Treatment in Children With Prader-Willi Syndrome: Three Years of Longitudinal Data in Prepubertal Children and Adult Height Data From the KIGS Database. J Clin Endocrinol Metab. 2017; 102(5): 1702-1711, doi: 10.1210/jc.2016-2962, indexed in Pubmed: 28323917. 
https://doi.org/10.1210/jc.2016-2962

15. Grugni, G., \& Marzullo, P. (2016). Diagnosis and treatment of GH deficiency in PraderWilli syndrome. Best Practice \& Research Clinical Endocrinology \& Metabolism, 30(6), 785-794. https://doi.org/10.1016/j.beem.2016.11.003

16. Goldstone AP, Holland AJ, Hauffa BP, et al. Speakers contributors at the Second Expert Meeting of the Comprehensive Care of Patients with PWS. Recommendations for the diagnosis and management of PraderWilli syndrome. J Clin Endocrinol Metab. 2008; 93(11): 4183-4197. https://doi.org/10.1210/jc.2008-0649

17. Crinò A, Fintini D, Bocchini S, Grugni G. Obesity management in Prader-Willi syndrome: current perspectives. Diabetes Metab Syndr Obes. 2018;11:579-593. https://doi.org/10.2147/DMSO.S141352

18. Tan Q, Orsso CE, Deehan EC, Triador L, Field CJ, Tun HM, et al. Current and emerging therapies for managing hyperphagia and obesity in Prader-Willi syndrome: A narrative review. Obes Rev. 2020 May;21(5):e12992. https://doi.org/10.1111/obr.12992

19. Diene G, Mimoun E, Feigerlova E, et al. French Reference Centre for PWS. Endocrine disorders in children with Prader-Willi syndrome-data from 142 children of the French database. Horm Res Paediatr. 2010; 74(2): 121-128,https://doi.org/10.1159/000313377

20. Deal CL, Tony M, Höybye C, Allen DB, Tauber M, Christiansen JS, et al. Growth Hormone Research Society workshop summary: consensus guidelines for recombinant human growth hormone therapy in Prader-Willi syndrome. J Clin Endocrinol Metab. 2013 Jun;98(6):E1072-1087. https://doi.org/10.1210/jc.2012-3888

21. Bakker NE, Kuppens RJ, Siemensma EPC, Tummers-de Lind van Wijngaarden RFA, Festen D a. M, Bindels-de Heus GCB, et al. Bone mineral density in children and adolescents with Prader-Willi syndrome: a longitudinal study during puberty and 9 years of growth hormone treatment. J Clin Endocrinol Metab. 2015 Apr;100(4):1609-18. https://doi.org/10.1210/jc.2014-4347

22. Bakker NE, Siemensma EPC, van Rijn M, Festen DAM, Hokken-Koelega ACS. Beneficial Effect of Growth Hormone Treatment on Health-Related Quality of Life in Children with Prader-Willi Syndrome: A Randomized Controlled Trial and Longitudinal Study. Horm Res Paediatr. 2015;84(4):231-9. https://doi.org/10.1159/000437141

23. Lo ST, Festen DAM, Tummers-de Lind van Wijngaarden RFA, Collin PJL, HokkenKoelega ACS. Beneficial Effects of Long-Term Growth Hormone Treatment on Adaptive Functioning in Infants With Prader-Willi Syndrome. Am J Intellect Dev Disabil. 2015 Jul;120(4):315-27. https://doi.org/10.1352/1944-7558-120.4.315

24. Kuppens RJ, Bakker NE, Siemensma EPC, Tummers-de Lind van Wijngaarden RFA, Donze SH, Festen DAM, et al. Beneficial Effects of GH in Young Adults With Prader-Willi Syndrome: A 2-Year Crossover Trial. J Clin Endocrinol Metab. 2016;101(11):4110-6. https://doi.org/

25. Hyde AM, Chavoya FA, Silveira FV, Beam WC, Rubin DA. Metabolic responses to walking in children with Prader-Willi syndrome on growth hormone replacement therapy. Am J Med Genet A. 2018;176(11):2513-6. https://doi.org/10.1210/jc.2016-2594

26. Corripio R, Tubau C, Calvo L, Brun C, Capdevila N, Larramona H, et al. Safety and 
effectiveness of growth hormone therapy in infants with Prader-Willi syndrome younger than 2 years: a prospective study. J Pediatr Endocrinol Metab. 2019 Aug 27;32(8):879-84. https://doi.org/10.1515/jpem-2018-0539

27. Kuppens RJ, Mahabier EF, Bakker NE, Siemensma EPC, Donze SH, Hokken-Koelega ACS. Effect of cessation of GH treatment on cognition during transition phase in PraderWilli syndrome: results of a 2-year crossover GH trial. Orphanet J Rare Dis. 2016 16;11(1):153. https://doi.org/10.1186/s13023-016-0535-7

28. Kuppens RJ, Bakker NE, Siemensma EPC, Donze SH, Stijnen T, Hokken-Koelega ACS. Metabolic health profile in young adults with Prader-Willi syndrome: results of a 2-year randomized, placebo-controlled, crossover GH trial. Clin Endocrinol (Oxf). 2017 Feb;86(2):297-304. https://doi.org/10.1111/cen.13247 